\title{
ANALISIS PENERAPAN KEGIATAN MENCAMPUR WARNA MENGGUNAKAN CAT AKRILIK UNTUK MENINGKATKAN PERKEMBANGAN KOGNITIF ANAK USIA DINI
}

\author{
Heni Herlina ${ }^{1}$, Larasati Nur Indah Prawesti ${ }^{2}$, dan Nunik Nurkomala ${ }^{3}$ \\ ${ }^{1}$ Sekolah Tinggi Keguruan dan Ilmu Pendidikan Banten \\ ${ }^{2}$ Sekolah Tinggi Keguruan dan Ilmu Pendidikan Banten \\ ${ }^{3}$ Mahasiswa Pendidikan Guru Pendidikan Anak Usia Dini \\ Penulis Korespondensi: heniherlina.ss.mpd@gmail.com ${ }^{1}$, iiazzprawesti@gmail.com $^{2}$, \\ niheelambara@gmail.com ${ }^{3}$ \\ $\begin{array}{ccc}\text { Artikel Kegiatan Mencampur Warna Menggunakan Cat Akrilik } \\ \text { Penerima: Januari, } 2021 & \text { Diterima: Februari, } 2021 \quad \text { Dipublikasikan: Maret, } 2021\end{array}$
}

ABSTRACT

Mixing colors is the result of mixing 2-3 basic colors into new colors. Meanwhile, early childhood cognitive development is a thought process in the form of the ability to connect, assess and consider things as well as the ability to solve problems or to create works. The purpose of this study was to determine the application of color mixing activities using acrylic paint on the development of cognitive abilities of early childhood. This research methodology uses qualitative methods and the type of research is literature study research. The results of research conducted by I Gusti Ayu Inten Anggreni, et al, there was an increase in cognitive ability in mixing colors in children by $91.07 \%$. Hidayat, Eka Cahya Maulidiyah, the average cognitive ability score of the class became 97.04\%, Elia Supriani, et al was $84.21 \%$, Uswatun Khasanah increased to 88\%, and Dek Ngurah Laba Laksana, et al. The results showed that the development of cognitive aspects of learning Early childhood consists of three aspects, namely aspects of learning and problem solving, aspects of logical thinking, and aspects of symbolic thinking. So it can be concluded that there is a positive influence on the application of color mixing activities using acrylic paint to improve cognitive development of early childhood.

Keywords: Mixing Acrylic Paint Colors, Early Childhood Cognitive Development

\begin{abstract}
ABSTRAK
Mencampur warna adalah hasil pencampuran 2-3 warna dasar menjadi warna-warna baru. Sedangkan Perkembangan kognitif anak usia dini adalah suatu proses berpikir berupa kemampuan untuk menghubungkan, menilai dan mempertimbangkan sesuatu serta kemampuan untuk memecahkan masalah atau untuk mencipta karya. Tujuan penelitian ini adalah untuk mengetahui penerapan kegiatan mencampur warna menggunakan cat akrilik terhadap perkembangan kemampuan kognitif anak usia dini. Metodologi penelitian ini menggunakan metode kualitatif dan jenis penelitiannya yaitu penelitian studi literatur. Hasil penelitian yang dilakukan oleh I Gusti Ayu Inten Anggreni, dkk terjadi peningkatan kemampuan kognitif dalam mencampur warna pada anak sebesar 91,07\%. Hidayat, Eka
\end{abstract}


Cahya Maulidiyah terdapat skor kemampuan kognitif rata-rata kelas menjadi 97.04\%, Elia Supriani, dkk yaitu $84.21 \%$, Uswatun Khasanah meningkat menjadi sebesar $88 \%$, dan Dek Ngurah Laba Laksana, dkk terdapat Hasil penelitian menunjukkan bahwa perkembangan aspek kognitif pada pembelajaran anak usia dini terdiri dari tiga aspek, yaitu aspek pembelajaran dan pemecahan masalah, aspek berpikir logis, dan aspek berpikir simbolik. Sehingga dapat ditarik kesimpulan bahwa terdapat pengaruh positif terhadap penerapan kegiatan mencampur warna menggunakan cat akrilik untuk meningkatkan perkembangan kognitif anak usia dini.

Kata kunci: Mencampur Warna Cat Akrilik, Perkembangan Kognitif Anak Usia Dini.

\section{PENDAHULUAN}

Masa anak usia dini sering dipandang sebagai masa emas (golden age). Dimasa ini anak mempunyai peluang yang sangat besar untuk pembentukan dan pengembangan pribadinya. Menurut pakar psikologi, anak usia dini merupakan masa yang tepatuntuk melakukan pendidikan. Sebab, pada masa ini anak sedang mengalami proses pertumbuhan dan perkembangan yang luar biasa. Anak belum memiliki pengaruh negatif yang banyak dari luar atau lingkungan sehingga orangtua maupun pendidik akan jauh lebih mudah dalam mengarahkan dan membimbing anak (Uswatun Khasanah, 2018).

Salah satu pembelajaran yang dapat dikenalkan pada anak yaitu mengenai konsep pencampuran warna. Anak melihat banyak warna di sekitarnya dalam kehidupan sehari-hari. Menurut Haith dalam Papalia kemampuan untuk mengikuti target yang bergerak juga berkembang pada saat bulan-bulan pertama, seperti halnya persepsi warna (Kartika Fajriani, Heppy Liana, 2019). Warna merupakan suatu media yang sangat menarik dilihat oleh anak didik. Anak yang memiliki rasa ingin tahu akan sangat suka membubuhkan warna di setiap media yang anak temui baik itu berupa gambaran dengan mengisi atau menghiasi bidang gambar yang ingin diwarnai. Terdapat banyak kegiatan anak

(C) 2021, JoEE, Jurnal of Early Childhood. PGPAUD e-ISSN: 2775-7870 usia dini yang ada kaitanya dengan warna seperti mewarnai gambar, melukis, finger painting, membatik dan jumputan, mencampur warna (bereksperimen) (I Gusti Ayu Inten Anggreni, dkk, 2018).

Dari pengertian diatas, dapat ditarik kesimpulan bahwa warna adalah suatu media yang sangat menarik untuk pembelajaran baik dengan mencampurkan warna atau menggnakan warna itu sendiri untuk menciptakan rasa ingin tahu anak usia dini dan juga untuk meningkatkan kognitif anak itu sendiri.

Selain itu istilah kognitif (Cognitive) berasal dari kata cognition yang artinya pengertian atau mengerti. Pengertian dalam area cognition (kognisi) adalah perolehan, penataan, dan penggunaan pengetahuan. Dalam perkembangan selanjutnya, istilah kognitif ini menjadi populer sebagai salah satu wilayah psikologi manusia atau salah satu konsep umum yang mencakup semua bentuk pengenalan yang meliputi setiap prilaku mental yang berhubngan dengan masalah pemahaman, memberikan, memperhatikan, mempertimbangkan, pengolahan informasi, pemecahan masalah, kesengajaan, membayangkan, memperkirakan, berpikir dan keyakinan (Herdina Indrijati, 2017).

Kognitif adalah suatu proses berpikir, yaitu kemampuan individu untuk menghubungkan, menilai dan mempertimbangkan suatu kejadian atau peristiwa (I Gusti Ayu Inten Anggreni, dkk, 
Heni Herlina, Larasati Nur Indah Prawesti, dan Nunik Nurkomala. Analisis Penerapan Kegiatan Mencampur Warna Menggunakan Cat Akrilik Untuk Meningkatkan Perkembangan Kognitif Anak Usia Dini

2018). Perkembangan kognitif anak usia dini adalah suatu proses berpikir berupa kemampuan untuk menghubungkan, menilai dan mempertimbangkan sesuatu serta kemampuan untuk memecahkan masalah atau untuk mencipta karya (Kartika F \& Heppy Liana, 2019)

Berdasarkan latar belakang masalah yang telah dipaparkan diatas, maka rumusan masalah yang muncul adalah: Bagaimana Penerapan Kegiatan Mencampur Warna Menggunakan Cat Akrilik terhadap perkembangan Kognitif Anak Usia Dini?. Tujuan dalam penelitian ini adalah untuk mengetahui penerapan kegiatan mencampur warna menggunakan cat akrilik terhadap perkembangan kemampuan kognitif anak usia dini.

\section{LANDASAN TEORI}

Sujiono menyatakan "Anak usia dini adalah sosok individu yang sedang menjalani suatu proses perkembangan dengan pesat dan fundamental bagi kehidupan selanjutnya". Khaironi menyatakan Aspek perkembangan anak usia dini ada 6 yaitu aspek perkembangan fisik motorik (kasar dan halus), aspek kognitif, aspek sosial dan emosional serta seni (Sujiono, 2013: 6).

Perkembangan kognitif anak usia dini adalah suatu proses berpikir berupa kemampuan untuk menghubungkan, menilai dan mempertimbangkan sesuatu serta kemampuan untuk memecahkan masalah atau untuk mencipta karya (Fijriati, 2019: 34).

Kemampuan kognitif adalah kemampuan yang diperoleh anak melalui dirinya sendiri dengan terlibat langsung dalam kegiatan pembelajaran. Untuk itu pendidik perlu mengatur kegiatan pembelajaran yang berpusat pada anak dalam mengembangkan dan memproses kemampuan berpikir yang spesifik agar anak dapat memecahkan suatu masalah melalui proses berfikir (Dian, 2018:20).

Piaget mengemukakan bahwa terdapat empat fase perkembangan kognitif. Ada empat tahap perkembangan yaitu: a. Tahap Sensorimotor, b. Tahap Praoperasional, c. Tahap Operasional Konkret, dan d. Tahap Operasional Formal (Dian, 2018:23-24).

Banyak faktor yang dapat mempengaruhi perkembangan kognitif, namun sedikitnya faktor yang memengaruhi perkembangan kognitif dapat dijelaskan sebagai berikut: factor hereditas atau keturunan, faktor lingkungan, faktor kematangan, faktor pembentukan, faktor minat dan bakat, dan faktor kebebasan (Hijriati, 2019:45).

Warna adalah sebuah sensasi yang di hasilkan suatu energi cahaya mengenai suatu benda dimana cahaya tersebut akan di refleksikan secara langsung oleh benda yang terkena cahaya tadi (Kartika, 2019: 34-35). Sedangkan Pengertian warna menurut Nugraha dan Dwiyana "warna adalah kesan yang diperoleh mata dari cahaya yang dipantulkan oleh bendabenda dikenainya (Anggrainil, 2018). Menurut Robinson pencampuran warna adalah memadukan warna primer (merah, biru, dan kuning) untuk mendapatkan semua warna yang diinginkan (Elia, 2018:2).

Menurut Fajriani warna dibagi menjadi dua kelompok, yaitu warna primer dan warna sekunder (Fijriati, 2019: 35). Indikator pencapaian perkembangan penampuran warna (eksperimen) menurut Uswatun Hasanah adalah Menunjukkan macam-macam warna, Percobaan pencampuran warna dari warna pokok, Meniru tulisan warna yang ada pada gambar, dan Menghubungkan warna yang ada pada gambar dengan kalimat disebelahnya (Khasanah, 2018: 15). 
Langkah-langkah pencampuran warna menggunakan cat akrilik adalah Siapkan cat dan semua peralatan yang dibutuhkan, Mulailah dengan mencampur tiga warna primer, tertier, sekunder dan netral., serta Pencampuran cat siap digunakan.

Kelebihan pencampuran warna adalah Media yang digunakan aman untuk anak, Media mudah ditemukan, Media mempunyai warna-warna yang bagus, dan Anak bisa mengekspresikan apa yang diarasakan dengan media tersebut (Khasanah, 2018: 31-32).

Kekurangan Pencampuran Warna adalah Media yang digunakan perlu pengawasan orang tua, Media digunakan satu kali pakai, Media mudah sekali rusak, dan Media rawan jika kena air (Khasanah, 2018: 31-32).

\section{METODOLOGI PENELITIAN}

Metode penelitian yang digunakan dalam penelitian ini adalah penelitian kualitatif. Sedangkan jenis penelitiannya yaitu penelitian kepustakaan dan studi pustaka/riset pustaka meski bisa dikatakan mirip akan tetapi berbeda. Studi literatur adalah serangkaian kegiatan yang berkenaan dengan metode pengumpulan data pustaka, membaca dan mencatat, serta mengelolah bahan penelitian. Studi Literatur adalah merupakan penelitian yang dilakukan oleh peneliti dengan mengumpulkan sejumlah buku buku, majalah yang berkaitan dengan masalah dan tujuan penelitian.

Teknik analisis data yang digunakan dalam penelitian dengan model dari (Miles dan Huberman) yang terdiri dari tiga tahap, antara lain reduksi data, penyajian data dan penarikan kesimpulan/verifikasi (Suarifki, 2018).

\section{HASIL DAN PEMBAHASAN Hasil}

Pada bab ini temuan penelitian berdasarkan hasil pengolahan dan analisis data. Teknik analisis data adalah proses sebuah proses penyederhanaan data ke dalam bentuk yang lebih mudah dibaca dan interprestasikan. Dalam menganalisis data, teknik analisis data yang digunakan dalam penelitian dengan model dari (Miles dan Huberman) yang terdiri dari tiga tahap, antara lain reduksi data, penyajian data dan penarikan kesimpulan/verifikasi.

Adapun langkah-langkah yang diambil adalah sebagai berikut: a. Pengumpulan data atau mengumpulkan data dari beberapa sumber, baik dari sumber data primer (jurnal dan skripsi terdahulu) dan sumber data sekunder (buku). b. Reduksi data atau merangkum data, c. Menyajikan (display) data yakni menyajikan data dalam penelitian kualitatif melalui sejumlah teks yang bersifat naratif, d. Menarik kesimpulan dan verifikasi sebagai jawaban terhadap rumusan masalah yang telah dituangkan sejak awal.

Dari Penyajian data primer dari jurnal dan skripsi terdahulu, dapat dianalisis hasil persentase terendah pada siklus I yaitu sebesar $31,58 \%$ dengan ratarata persentasenya adalah 41,46\%, sedangkan hasil persentase tertinggi pada siklus II yaitu $97,04 \%$ dengan ratarata persentasenya $89,83 \%$. Sehingga tarap peningkatan persentasenya adalah 48,37\%. Dari data diatas, perubahan peningkatannya naik secara signifikan.

Dari sumber data primer dan sumber data sekunder dari penelitian diatas, dapat ditarik kesimpulan bahwa terdapat pengaruh positif terhadap penerapan kegiatan mencampur warna menggunakan cat akrilik untuk 
| Heni Herlina, Larasati Nur Indah Prawesti, dan Nunik Nurkomala. Analisis Penerapan Kegiatan Mencampur Warna Menggunakan Cat Akrilik Untuk Meningkatkan Perkembangan Kognitif Anak Usia Dini

meningkatkan perkembangan kognitif anak usia dini.

\section{Pembahasan}

Hasil pembahasan pengumpulan data atau mengumpulkan data dari beberapa sumber, baik dari sumber data primer (jurnal dan skripsi terdahulu) dan sumber data sekunder (buku). Yaitu penelitian sumber data primer yang dikaji dan dianalisis sebanyak 5 penelitian baik dari skripsi terdahulu atau jurnal. Sedangkan sumber data sekunder yang dikaji sebanyak 3 buku penelitian.

Dari sumber data primer dari penelitian diatas, dapat ditarik kesimpulan bahwa terdapat pengaruh positif terhadap penerapan kegiatan mencampur warna menggunakan cat akrilik untuk meningkatkan perkembangan kognitif anak usia dini.

Dari sumber data sekunder dapat disimpulkan bahwa kognitif adalah sebuah istilah yang digunakan oleh psikologi untuk menjelaskan semua aktivitas mental yang berhubungan dengan persepsi, pikiran, ingatan, dan pengolahan informasi yang memungkinkan seseorang memperoleh kemampuan, memecahkan masalah, dan merencanakan masa depan, atau semua proses psikologi yang berkaitan dengan bagaimana individu mempelajari, memperhatikan, mengamati, membayangkan, memperkirakan, menilai dan memikirkan lingkungannya. Piaget mengemukakan bahwa terdapat empat fase perkembangan kognitif. Ada empat tahap perkembangan yaitu: tahap sensorimotor, tahap praoperasional, tahap operasional konkret, dan tahap operasional formal.

(C) 2021, JoEE, Jurnal of Early Childhood. PGPAUD e-ISSN: 2775-7870

\section{PENUTUP Simpulan}

Berdasarkan hasil temuan dalam penelitian yang sudah dilakukan peneliti dengan metodologi studi literatur, dapat disimpulkan bahwa terdapat pengaruh positif terhadap penerapan kegiatan mencampur warna menggunakan cat akrilik untuk meningkatkan perkembangan kognitif anak usia dini..

\section{Saran}

Berdasarkan hasil penelitian dengan menggunakan metode penelitian studi literatur, penulis memberikan saran sebagai berikut:

1. Bagi Siswa

Disarankan kepada siswa untuk meningkatkan perkembangan kognitif Anak Usia Dini dengan mencampur warna.

2. Guru

Guru diharapkan agar dapat menerapkan kegiatan mencampur warna menggunakan cat akrilik, untuk meningkatkan perkembangan kognitif anak usia dini

3. Sekolah

Diharapkan kepada pihak sekolah agar dapat melengkapi fasilitas belajar khususnya fasilitas yang berkenaan dengan penunjang kemampuan siswa.

4. Peneliti

Bagi peneliti lain hendaknya melanjutkan penelitian ini agar manfaat dari penerapkan kegiatan mencampur warna menggunakan cat akrilik, untuk meningkatkan perkembangan kognitif anak usia dini ini bisa lebih maksimal.

5. Pembaca

Diharapkan kepada para pembaca untuk menjadikan penelitian ini menjadi salah satu referensi pengetahuan khususnya mengenai menerapkan kegiatan mencampur 
warna menggunakan cat akrilik, untuk meningkatkan perkembangan kognitif anak usia dini. Dengan adanya metode penelitian studi literatur diharapkan menjadi pedoman bagi penelitian selanjutnya karena masih sedikit penelitian yang menggunakan studi literatur sebagai metode penelitiannya.

\section{DAFTAR PUSTAKA}

Arum Setiyawat, Dian. (2018). Peningkatan Kemampuan Kognitif Mewarnai Melalui Metode Bermain Warna pada Anak Kelompok $A_{4}$ RA Al Hikmah Ungaran Tahun Pelajaran 2017/2018. Pendidikan Islam Anak Usia Dinifakultas Tarbiyah dan Ilmu Keguruan. Institut Agama Islam Negeri (IAsIN) Salatiga.

Citra Utami, Lita. (2020). Meningkatkan Kemampuan Mengenal Warnaanak Usia 3-4 Tahun Melalui Bermain Sains. Program Studi Pendidikan Guru Pendidikan Anak Usia Dini. Universitas Muhammadiyah Jember.

Dek Ngurah Laba Laksana, dkk. (2019). JPI, Vol. 8 No. 2, Oktober 2019ISSN: 2541-7207 DOI: $10.23887 / j p i-$ undiksha.v8i2.19481 Jurnal Pendidikan Indonesia : Developing Early Childhood Cognitive Aspects Based on Anderson And Krathwohl's Taxonomy. Elementary Teacher Education. Department, STKIP Citra Bakti, Bajawa. Early Childhood Teacher Education Department, STKIP Citra Bakti, Bajawa.

Desmita. (2016). Psikologi Perkembangan. Bandung: PT Remaja Rosdakary.

Diantama, Suarifqi. (2018). Metode Penelitian Pendidikan. Bandung: Pustaka Rahmat.

(C) 2021, JoEE, Jurnal of Early Childhood. PGPAUD e-ISSN: 2775-7870
Fajriani, Kartika Heppy Liana. (2019). Upaya Meningkatkan Kemampuan Kognitif Anak Usia 5-6 Tahun Melalui Permainan Pencampuran Warna dengan Percobaan Sains Sederhana Di TK Islam Silmi Samarinda. Dosen Universitas Nahdlatul Ulama Kaltim.

Femmy Nur Assyifa, Rohita, \& Nurfadilah.(2020). Pengaruh Video Pembelajaran Interaktif Mengenal Warna Terhadap Kemampuan Kognitif Anak. Program Studi Pendidikan Guru Pendidikan Anak Usia DiniUniversitas Al-Azhar Indonesia.

Hidayat, Eka Cahya Maulidiyah,. (2016). Peningkatan Kemampuan Kognitif Anak Melalui Kegiatan Membilang Benda Sekitar. TK Budi Utomo Lamongan; IAIN Tulungagung.

Hijriati. (2019). Tahapan Perkembangan Kognitif Pada Masa Early Childhood. . Pasca Sarjana Pendidikan Guru Raudhatul Athfal UIN Sunan Kalijaga Yogyakarta.

https://elibrary.unikom.ac.id/id/eprint/155 8/8/11.\%20UNIKOM 41815217 Dez ara\%20Judithia\%2oHandriani_BAB \%20lll.pdf.

I Gusti Ayu Inten Anggreni, I Made Suara, I Komang Ngurah Wiyasa. (2014). Meningkatkan Kemampuan Kognitif Sains Dalam Mencampur Warna Melalui Penerapan Metode Eksperimen Pada Anak Kelompok B. Universitas Pendidikan Ganesha Singaraja, Indonesia.

Herdina Indrijati. (2017). Psikologi Perkembangan dan Pendidikan Anak Usia Dini Sebuah Bunga Sampai. Jakarta: Kencana 
Heni Herlina, Larasati Nur Indah Prawesti, dan Nunik Nurkomala. Analisis Penerapan Kegiatan Mencampur Warna Menggunakan Cat Akrilik Untuk Meningkatkan Perkembangan Kognitif Anak Usia Dini

Khadijah. (2016). Pengembangan Kognitif Anak Usia Dini. Medan: Perdana Publishing.

Khasanah, Uswatun. (2018). Peningkatan Kemampuan Sains Melalui Kegiatan Pencampuran Warna Pada Anak Kelompok B TK Siwi Pertiwi Kecamatan Bancak Kabupaten Semarang Tahun Pelajaran 2018/2019. Program Studi Pendidikan Islam Anak Usia Dini Fakultas Tarbiyah Dan IImu Keguruan Institut Agama Islam Negeri Salatiga.

Muhammad Busyro Karim, Siti Herlinah Wifroh. (2019). Meningkatkan Perkembangan Kognitif Pada Anak Usia Dini melalui Alat Permainan Edukatif. Program Studi Pendidikan Guru Pendidikan Anak Usia Dinifakultas Keguruan Dan Ilmu Pendidikanuniversitas Trunojoyo Madura.

Ni Made Windhi Prastika Dewi, Nyoman Jampel, Luh Ayu Tirtayani. (2016). Meningkatkan Kemampuan Sains Melalui Penerapan Metode Eksperimen Pada Kelompok A. Fakultas Ilmu Pendidikan Universitas Pendidikan Ganesha Singaraja, Indonesia

Sugiyono. 2016. Metode Penelitian Kombinasi (Mixed Method). Bandung: Alfabeta,

Sujiono, Y.N. (2013). Konsep Dasar Pendidikan Anak Usia Dini. Jakarta: Indeks.

Supriani, Elia. Peduk Rintayati, Yudianto Sujana. (2018). Penerapan Pengetahuan Tentang Pencampuran Warna Melalui Metode Bermain Untuk Meningkatkan Kreativitas Anak Kelompok B TK Mutiara Tahun
Ajaran 2017/ 2018. Program Studi Pg-Paud, Universitas Sebelas Maret. 